\section{Announcement of 2008 Annual Meeting}

$\mathrm{T}$ The Eighty-eighth Annual Meeting of The American Association for Thoracic Surgery will be held May 10-14, 2008, in San Diego, CA, at the San Diego Convention Center. The meeting of the Association is open to all physicians. House Officers and Fellows will be admitted without payment of a registration fee upon presentation of a letter from their Chief of Service either during preregistration or at the time of registration.

\section{Requests for Preregistration Forms and Hotel Reservations}

Information about the 2008 Annual Meeting, including registration, hotel accommodations, and the social program, will be available on the AATS website at www.aats.org in December.

\section{Call for Abstracts}

Abstract submission for the 2008 program is now open. Essayists selected for the program are reminded that papers presented at the meeting are to be submitted for consideration for publication to The Journal of Thoracic and Cardiovascular Surgery and must be submitted to the JTCVS via the Internet prior to the Annual Meeting. Papers that are selected by the AATS Program Committee may not be presented or published elsewhere prior to the Annual Meeting in 2008.

\section{Applications for Membership}

Applications for membership in the Association are available online at www.aats.org no later than November 2007. Applications received after that date are deferred automatically for consideration until the 2008 meeting.

\section{Evarts A. Graham Memorial Traveling Fellowship, 2008-2009}

$\mathrm{T}$ he Evarts A. Graham Memorial Traveling Fellowship was established in 1951 by The American Association for Thoracic Surgery. Administered through the Graham Education and Research Foundation, Fellowship grants support study by young cardiothoracic surgeons from outside North America at sites of their choice within North America and include travel between sites. Goals of the program are to broaden overall training and increase international contacts. Each Fellow should plan to have one primary center for his/her activities where he/she should spend six to nine months. The Fellow should have identified an individual at that center who will act as his/her sponsor and assist in planning the course of study at the host institution and at other institutions. In addition to the primary center, the Fellow is encouraged to plan to spend shorter periods of time at other secondary centers to enhance the Fellowship experience.

Awards are made to surgeons of unique promise who have been regarded as having the potential for later international thoracic surgical leadership. Since the inception of the Graham Fellowship, 55 young surgeons from 27 countries have been named for the Fellowship.

The Fellowship provides a stipend of $\$ 75,000$, a major portion of which is intended for travel expenses incurred when visiting other medical centers. The Fellowship also provides two round-trip coach air fares from the recipient's country to his/her primary center. The dates of the beginning and ending of the Fellowship year should be scheduled to coincide with the Annual Meetings of The American Association for Thoracic Surgery. The Fellow will be introduced at the May 2008 meeting, which will take place in San Diego, California, May 10-14. The Fellow will be expected to provide a written summary of his/her experience to the membership prior to its 2009 Annual Meeting, which will take place in Boston, Massachusetts, May 9-13.

The Fellow should become involved predominantly with observation, consultation, teaching, and research at a variety of thoracic surgical training centers during the twelve months. Patient contact will be determined by the sponsoring surgeon and will conform to the regulations and licensing requirements of the state, province, or country in which he/she is studying.

A candidate should have completed his/her formal training in general surgery and in thoracic and cardiovascular surgery, but he/she should not have reached a senior position. Candidates must be sufficiently proficient in English to realize the full benefits of the Fellowship. Candidate should not have had extensive clinical training in North America prior to making application, and should be planning to return to their native country following the completion of their fellowship. "Extensive" clinical training shall mean any period of clinical training which exceeds a total of six months in duration.

The online application submission site has been available beginning March 2007 at www.aats.org. All applications must have been submitted electronically via the online application submission site no later than July $\mathbf{1 , 2 0 0 7}$. The selected candidate will be notified by November 1, 2007.

\section{Resident Traveling Fellowship, 2007-2008}

$\mathrm{T}$ The American Association for Thoracic Surgery announces the Resident Traveling Fellowship, a program established to broaden the educational experience of residents in their final year of an approved cardiothoracic surgical training program by providing an opportunity to spend up to two weeks at one or more institutions other than their home institution.

A grant of $\$ 7,500$ will be provided to successful applicants to underwrite their travel and living expenses incurred during up to two weeks of training at one or more host institutions. The funds are also intended to provide for roundtrip travel and four nights' accommodations at the annual meeting of the Association scheduled for May 10-14, 2008 in San Diego, California. The fellowship must be completed prior to March 31, 2008.

Applicants must have the approval of their home and prospective host institutions. Candidates must complete an AATS application and include a one-page outline of what they hope to accomplish during their training. Additionally, award recipients must agree to submit a summary report to the membership of the association within thirty days after the completion of their training.

The candidate must be a North American resident in their final year of an ACGMF approved cardiothoracic surgical training program.

Applications are available online at www.aats.org and must have been completed no later than July 1, 2007. The selected candidates will be notified by September 30, 2007. 